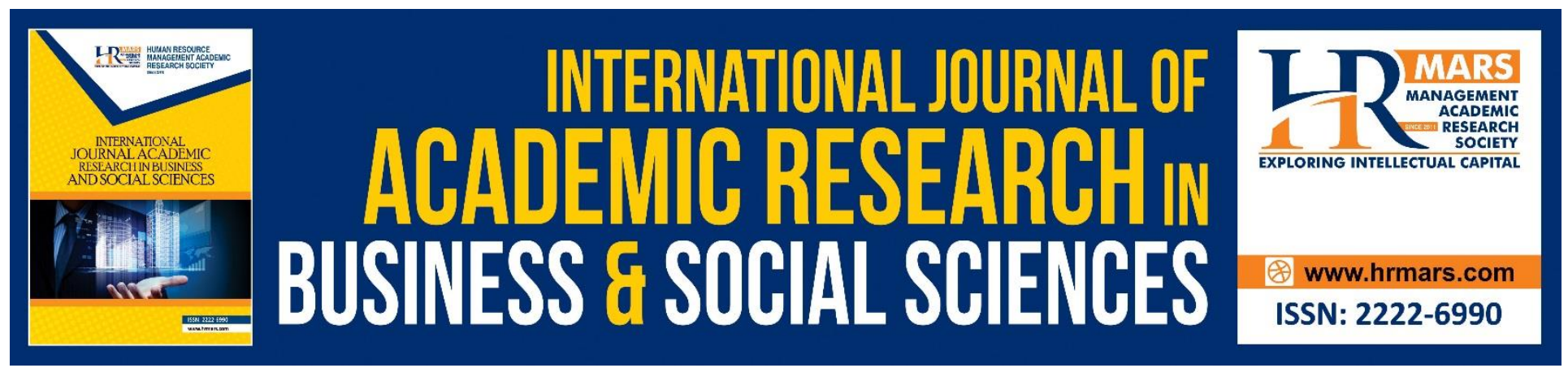

\title{
Ownership Structure and Firms' Performance: Evidence from Finance Sector in Malaysia
}

Siti Mariam Ismail, Nazaria Md. Aris, Ahmad Syubaili Mohamed, Suzila Mohamed Yusof, Nurul Syuhada Zaidi

To Link this Article: http://dx.doi.org/10.6007/IJARBSS/v10-i7/7418

DOI:10.6007/IJARBSS/v10-i7/7418

Received: 09 April 2020, Revised: 16 May 2020, Accepted: 11 June 2020

Published Online: 29 July 2020

In-Text Citation: (Ismail et al., 2020)

To Cite this Article: Ismail, S. M., Aris, N. M., Mohamed, A.S., Yusof, S. M., \& Zaidi, N. S. (2020). Ownership Structure and Firms' Performance: Evidence from Finance Sector in Malaysia. International Journal of Academic Research in Business and Social Sciences, 10(7), 319-329.

\section{Copyright: (c) 2020 The Author(s)}

Published by Human Resource Management Academic Research Society (www.hrmars.com)

This article is published under the Creative Commons Attribution (CC BY 4.0) license. Anyone may reproduce, distribute, translate and create derivative works of this article (for both commercial and non-commercial purposes), subject to full attribution to the original publication and authors. The full terms of this license may be seen at: http://creativecommons.org/licences/by/4.0/legalcode

Vol. 10, No. 7, 2020, Pg. $319-329$

Full Terms \& Conditions of access and use can be found at http://hrmars.com/index.php/pages/detail/publication-ethics 


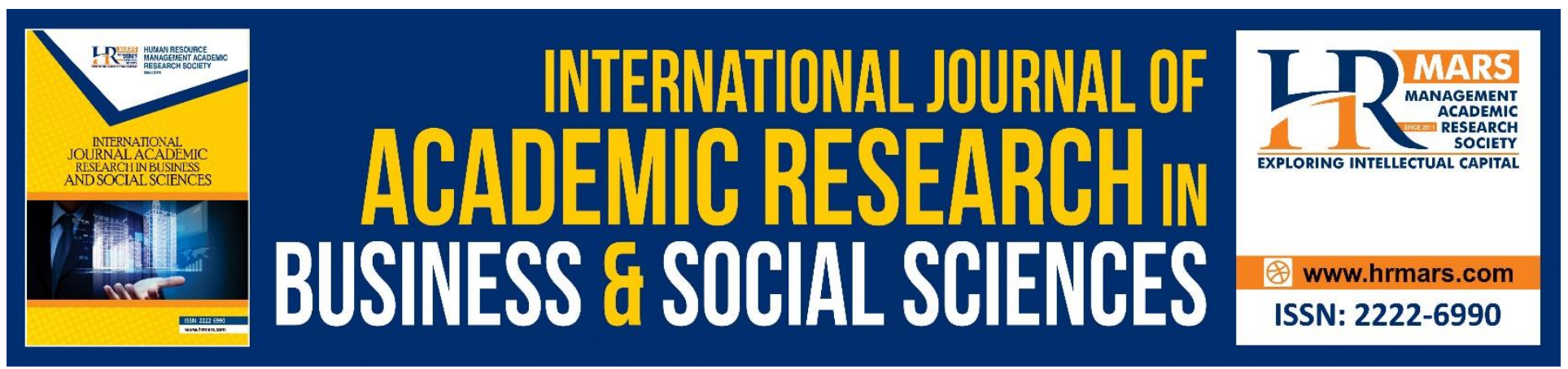

\title{
Ownership Structure and Firms' Performance: Evidence from Finance Sector in Malaysia
}

\author{
Siti Mariam Binti Ismail, Nazaria Binti Md. Aris, Ahmad Syubaili \\ Mohamed, Suzila Mohamed Yusof, Nurul Syuhada Bt. Zaidi \\ Faculty of Economics and Business, Universiti Malaysia Sarawak, Kota Samarahan, Sarawak \\ Email:manazaria@unimas.my
}

\begin{abstract}
Corporate governance is an internal control system that is essential for sustainable growth and continuous improvements to cater the needs of all parties involved, including investors, employees, customers and shareholders. The study of significance of ownership structure to the firms' performance in Malaysia is not done extensively in Malaysia. This study gives a better understanding on the issue to strengthen such structures. The corporate governance have been used to address the issue of ownership structure. It is stated that corporate governance can reduce the conflict of interest among shareholder and management. This paper examines the relationship between ownership structure variables and firms' performance using a sample of 14 firms that listed in Bursa Malaysia in finance sector from 2010 to 2014. Firms' performance is measured using return on assets (ROA) while managerial ownership (MO) and foreign ownership (FO) represents ownership structure variables. The results from random effects model reveal that the variables are insignificant but they have the positive relationship. From these findings, it revealed that managerial ownership has a positive impact on performance supported by numerous research that had been done.
\end{abstract}

Keywords: Corporate Governance, Managerial Ownership, Foreign Ownership, Return on Assets.

\section{Introduction}

Corporate governance gives a structure of control systems that help the organization in accomplishing its objectives, while avoiding undesirable conflicts. The pillars of corporate governance consist of ethical behavior, accountability, transparency, and sustainability are essential to the corporate governance. Organization that grasp these standards are bound to deliver long term value than those that are lacking in one or all. Corporate governance is not only concern with the investor interest but requires adjusting the needs of managements. In addition, the Malaysian Code on Corporate Governance (MCCG) presented in 2000 has been a significant tool for corporate governance reform and has impacted corporate governance practices of companies positively. The MCCG reflects global principles and internationally recognized practices of corporate governance which are above and beyond the minimum required by statute, regulations or those prescribed by Bursa Malaysia. The MCCG was reviewed in 2007 and 2012 to ensure that it remains relevant and is 
aligned with globally recognized best practices and standards. Prior scholars and analyst of corporate governance, Fama \& Jensen, (1983) have concentrated on the most proficient method to manage principal-agent problem that happens from the detachments of ownership and controls. These ongoing events and the difficulties have supported taking diverse measures over the world. For example, the Act of Sarbanes-Oxley in 2002 which manages the corporate governance framework to guarantee consistence to the standards of good corporate governance. At that point, the Jordanian government set up the first corporate governance code in 2009. Consequently, great corporate governance prompts better firms' performance. Larger part of the prior researches have conceded that corporate governance positively leave impact on the firms' performance. Kren and Kerr (1997), stated that expanding in the share stock for the supervisors or expanded managerial ownership is the mechanism to enhances the performance if the organizations.

\section{Corporate Governance}

Consciousness of good corporate governance are developed in the year 2000 (Bebchuk et al., 2013). Markets likewise appeared to take in this and join. The competent market theory predicts that trading on generally held data won't return extraordinary profits. Three factors was used to gauge the consideration paid to corporate governance such as corporate governance investors' goal by institutional speculators, references in the media and research conduct into the corporate governance. It demonstrate that consideration regarding corporate governance expanded strongly amid the 2000s which is a lot higher than that found during 1990s. Claessens \& Yurtoglu, (2013) give a review of corporate governance in developing markets. The result shows that after the Financial Crisis 1997, the nations in Asian have been reconstructed their corporate governance frameworks. It is trusted that poor corporate governance was the primary driver of the crisis. When all is said is done, changes appears to bring positives outcomes such as increments in share price. Furthermore, Rajagopalan \& Zhang, (2008) state that well-working corporate governance instruments in developing economies are vital and significance for both regional and foreign organizations which are keen on seeking after the gigantic open doors for ventures and development that growing economies give. From the viewpoint of regional organizations, there is proven that firms in developing economies which contrasted with their parents in emergent nations are limited to the financial markets as a result of their powerless governance (Barberis et al., 2000). Upgrades in corporate governance in developing economies for organizations can boost shareholders' certainty and increment these firms' entrance to capital (Rajagopalan \& Zhang, 2008). In order to conquer the issues in corporate governance, either in internal or external tools can be used. Essentially, the internal tools are the management and the value of ownership structure of the organizations, though essential external components are the outside market for corporate restrictions (the takeover market) and the legitimate framework. Internal and external governance components are correlative to one another. Nations which the market for corporate restrictions is not much common and authorization of corporate government directions through legitimate framework is frail give a solid case to inside governance systems to be at the front line for enhancing corporate performance (Denis \& McConnell, 2002).

\section{Managerial Ownership}

According to the study conducted by Demsetz \& Lehn et al., (1985) which apply cross sectional information demonstrate that the dimension of managerial ownership is dictated by the hazard of 
the firm, estimated by the unpredictability of the stock price. They contend that the degree for moral hazard is more noteworthy for superior of unhealthy organizations. In this manner, it implies that those superior must have more prominent ownership stakes to adjust its impetus. The managerial ownership and firm performance are significantly related to each other as a result of study conducted by Morck, Shleifer, \& Vishny (1988) even though the relationship is nonlinear. The idea nonlinearity varied between the two researches. Earlier researches have commonly utilized the examples of organizations drawn from an extensive cross-section of corporations and the additionally will in general treat ownership as exogenic. But, there is a few researches discover proof that managerial ownership is endogenous and relies upon the firm inside and outside condition. Extract from the prior study, the managerial ownerships seems to have relation with the firms' performance. To the degree that ownership structure adjust the benefit to the superior and investor, firms with large managerial ownership are probably going to exceed from those where ownership structure is small (Li, Moshirian, Nguyen, \& Tan, 2007). This viewpoint seems, by all accounts, to be very much bolstered. Therefore, based on the discussion, the first hypothesis can be developed as:

\section{H1: Managerial ownership affects firms' performance positively.}

\section{Foreign Ownership}

A study by Goethals and Ooghe (1997) found a positive correlation between foreign ownership and firm performance. The study conducted by utilizing regression analysis by taking 25 Belgian firms and 50 foreign companies that was domestic organizational taken by the outsider. The result is the organizations with foreign ownership performance was better in contrast with locally ownership. Other than that, Vural-yavas \& Erdogan, (2016) additionally take a look on performance of UK organizations procured by outsiders. The discoveries on 333 abroad acquisitions by UK limited companies from the 1984-1995 uncover a positive yield for the performance. Another research conducted by Gunduz \& Tatoglu, (2003) related to outsiders owned corporations performance in Turkey in the year 1999. The one-way analysis of variance (ANOVA) was utilized in the study to analyze the impact of foreign ownership on performance. As much as 202 non-financial organizations was selected from the ISE. The discoveries uncover that outsider owned organizations have fundamentally preferable performance in regards with ROA, yet not in other budgetary performance proportions. From the prior researches conduct, we can conclude that in the emergent nations, foreign ownership positively affect the profitability. At the end of the day, discoveries present a compromise of these previous researches. Therefore, the second hypothesis is constructed as;

\section{H2: Foreign ownership affects firms' performance positively}

\section{Research Methodology}

In this study, the relationship between ownership structure variables and firms' performance is being investigated. In this context, the target population is 14 organizations under the finance sector listed in Bursa Malaysia for the year 2010 until 2014. This study used both primary and secondary data. Statistical analysis were used to analyze the data i.e. descriptive analysis, Pearson's Correlation Matrix, Normality Test, Hausman Test, and Multicollinearity Test. The secondary data were from annual report acquired from official webpage of Bursa Malaysia and DataStream database. In this study; managerial ownership and foreign ownership are the independent variables, and return on assets (ROA) is the dependent variable. The theoretical model of study is shown in Figure 1. 
INTERNATIONAL JOURNAL OF ACADEMIC RESEARCH IN BUSINESS AND SOCIAL SCIENCES Vol. 10, No. 7, July, 2020, E-ISSN: 2222-6990 @ 2020 HRMARS

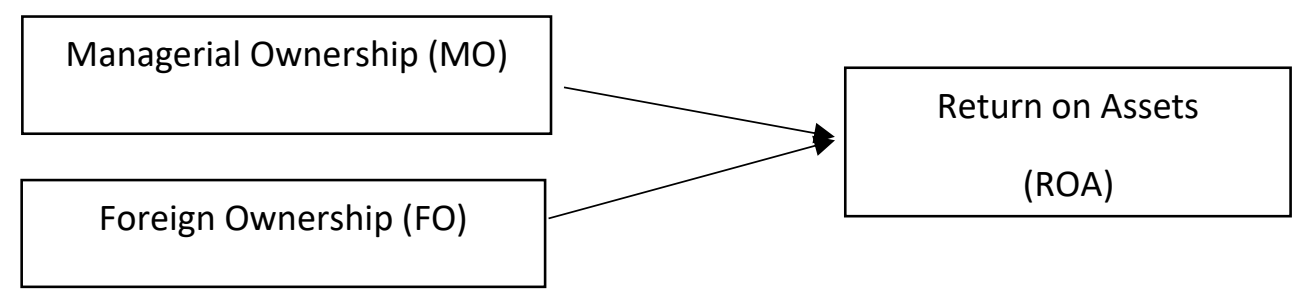

\section{Findings}

Figure 1: Theoretical Model

Descriptive Analysis

Table 1 shows that the result of descriptive statistic of the relationship between ownership structure and firms' performance which included mean, standard deviation, minimum and maximum value of dependent and independent variables.

\begin{tabular}{|l|l|l|l|l|l|}
\hline Variables & Observations & Mean & Std. Deviation & Minimum & Maximum \\
\hline ROA & 67 & 1.454303 & 0.899094 & -1.237874 & 3.294725 \\
\hline MO & 67 & 3.532582 & 0.560904 & 2.383243 & 4.481533 \\
\hline FO & 67 & 4.010130 & 0.473174 & 2.453588 & 4.490433 \\
\hline
\end{tabular}

Table 1: Descriptive Analysis

The dependent variables which is ROA shows that the performance of the firms have a value of mean as much as 1.45 and the standard deviation recorded was 0.90 . Then, for the first explanatory variable, the $\mathrm{MO}$ has the mean of 3.532. Therefore, the minimum and the maximum values for the MO were 2.383 and 4.482 respectively. The next explanatory variable which is FO has an average as much as 4.010 with the minimum and maximum value which were 2.454 and 4.490 . Each variable has a value of standard deviation are 0.561 and 0.473 respectively.

\section{Correlation Analysis}

This correlation analysis explains the relationship as well as the strength and direction either positive or negative among all the variables in the study by using correlation analysis.

\begin{tabular}{lccc}
\hline Variables & LROA & LMO & LFO \\
\hline LROA & 1.000000 & & \\
& ---- & & \\
LMO & ---- & & \\
& 0.324480 & 1.000000 & \\
& 2.765688 & ---- & \\
LFO & $(0.0074)^{* * *}$ & ---- & \\
& -0.335182 & -0.891764 & 1.000000 \\
& -2.868244 & -15.88867 & ---- \\
& $(0.0056)^{* * *}$ & 0.0000 & ---- \\
\hline
\end{tabular}

Notes: $* * *$ denote statistically significant at $1 \%$ level respectively.

Table 2: Pearson's Correlation Analysis

From the table above, the association between $\mathrm{MO}$ and ROA tends to have a moderate positive relationship between each other with the amount of 0.3245. It is once stated that there is a positive correlation between performance and ownership structure as well as the scale of Assets (Jiang, 2004). 
Meanwhile, the correlation between FO and ROA is moderately negative relationship as much as 0.3352. It is contrast with the study that conducted by Ongore, 2011 which found that the FO has a positive effect on firm performance. Next, the strength of a relationship measure by using the size of sample as well as the statistical significance is considered. But, the direction of the relationship does not affect the strength of a relationship. The table below shows how to measure the strength of a relationship.

\section{Normality Test}

From the diagram below, it shows the normality test for model 1 . The error term should be normally distributed for a good model. Based on the Normality Test, it shows that it is higher than the $90 \%$ significance level which was $0.425289>0.1$. It identifies that for the model 1 the null hypothesis is not been rejected. Hence the error term for the model 1 is normally distributed. Thus, the model 1 pass the third assumption of Classical Linear Regression Model (CLRM) which is zero mean for error term. As a conclusion, the result shows a good sign of model 1.

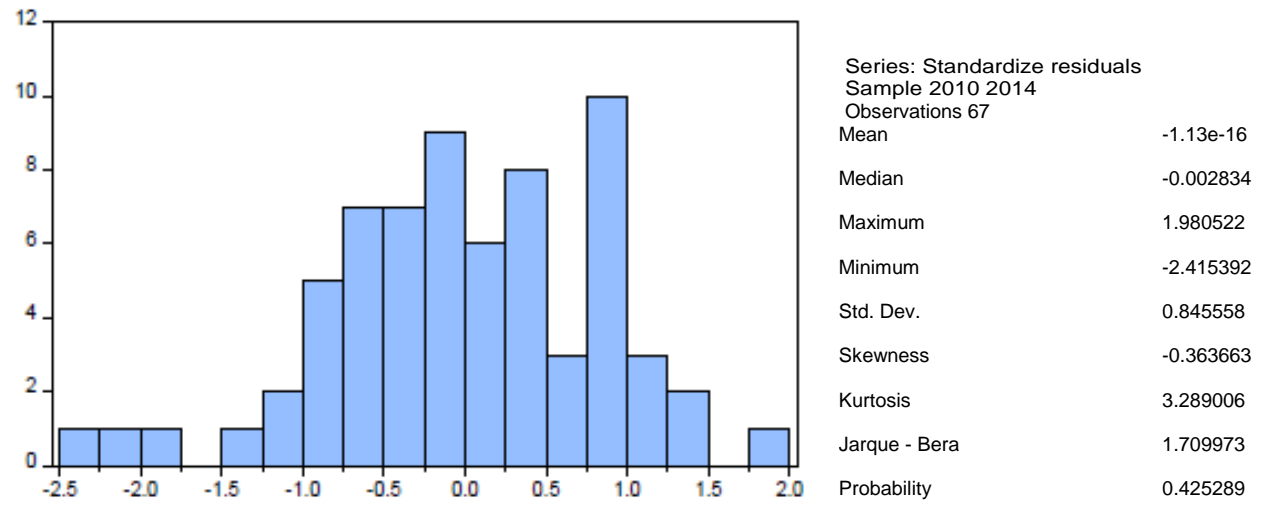

Figure 2: Normality Test

\section{Hausman Test}

The Hausman Test is conducted in order to choose whether the data using the fixed effects model or random effects model, which is more appropriate to use. The result of Hausman test are illustrated in table below.

\begin{tabular}{|l|l|l|l|}
\hline Test Summary & Chi-Sq. Statistic & Chi-Sq. d.f. & Prob. \\
\hline Cross-section random & 1.057806 & 2 & 0.5893 \\
\hline
\end{tabular}

Table 3: Hausman Test

The results from the table above shows that the p-value is 0.5893 , which is higher than 0.1 and it shows that the result is not statistically significant. Therefore, the null hypothesis can be rejected at $10 \%$ significance level. The rejection of null hypothesis concluded that random effects model is more appropriate for ROA in this study.

\section{Random Effect Model}

This unrestricted model is a random effects specification that use Swamy and Arora estimators for the component variances, and the estimates of the cross-section and idiosyncratic random effects 
INTERNATIONAL JOURNAL OF ACADEMIC RESEARCH IN BUSINESS AND SOCIAL SCIENCES Vol. 10, No. 7, July, 2020, E-ISSN: 2222-6990 @ 2020 HRMARS

standard deviations are 0.6232 and 0.6495 , respectively. Based on table 4 below, the estimated regression model is as follows:

$$
\mathrm{ROA}=1.2578+0.2329 \mathrm{MO}-0.1510 \mathrm{FO}
$$

Dependent Variable: ROA

Method: Panel EGLS (Cross-section random effects)

Swamy and Arora estimator of component variances

\begin{tabular}{lllll}
\hline Variable & Coefficient & Std. Error & t-Statistic & Prob. \\
\hline C & 1.257819 & 4.807057 & 0.261661 & 0.7944 \\
MO & 0.232859 & 0.593673 & 0.392234 & 0.6962 \\
FO & -0.151041 & 0.706857 & -0.213680 & 0.8315 \\
R-squared & 0.026867 & & F-statistic & 0.883480 \\
$\begin{array}{l}\text { Adjusted R- } \\
\text { squared }\end{array}$ & -0.003543 & & Prob(F- & 0.418322 \\
\hline & & & statistic) & \\
\hline Cross-section & Effects Specification & & \\
random & & & S.D. & Rho \\
Idiosyncratic & & 0.623246 & 0.4794 \\
random & & & 0.5206 \\
\hline
\end{tabular}

Table 4: Random Effect Model

From this estimated regression, the firm performance will be at the level 1.2578 when the explanatory variables are zero. This suggest that the firms in Malaysia still achieve some level of financial performance regardless of the types of the ownership. When one unit of managerial ownership increase, the ROA will increase by 0.2329 unit, holding other variables constant. So, the managerial ownership and firm performance has a positive relationship between each other. However, when the foreign ownership increase by one unit, the ROA will decrease as much as 0.1510 unit, holding another variable constant. It shows that both are not positively correlated which means that the foreign ownership and the firms' performance has a negative relationship. 
INTERNATIONAL JOURNAL OF ACADEMIC RESEARCH IN BUSINESS AND SOCIAL SCIENCES Vol. 10, No. 7, July, 2020, E-ISSN: 2222-6990 @ 2020 HRMARS

Random Effects Model Result

\begin{tabular}{lllll}
\hline Variable & Coefficient & Std. Error & t-Statistic & Prob. \\
\hline C & -0.811011 & 7.246184 & -0.111923 & 0.9113 \\
LMO & 0.309196 & 0.889833 & 0.347477 & 0.7297 \\
LFO & 0.292522 & 1.070376 & 0.273289 & 0.7857 \\
\hline
\end{tabular}

Effects Specification

Cross-section fixed (dummy variables)

\begin{tabular}{llll}
\hline & & & \\
R-squared & 0.596733 & Mean dependent var & 1.454303 \\
Adjusted R-squared & 0.478125 & S.D. dependent var & 0.899094 \\
S.E. of regression & 0.649513 & Akaike info criterion & 2.179558 \\
Sum squared resid & 21.51523 & Schwarz criterion & 2.706051 \\
Log likelihood & -57.01518 & Hannan-Quinn criter. & 2.387892 \\
F-statistic & 5.031145 & Durbin-Watson stat & 1.881385 \\
Prob(F-statistic) & 0.000007 & & \\
\hline
\end{tabular}

Table 5: Random Effect Model Result

The estimation model is obtained from the result based on the Table 5 which is:

$$
\mathrm{ROA}=-0.8110+0.3092 \mathrm{MO}+0.2925 \mathrm{FO}
$$

From the regression model above, the level of independent and explanatory variables is zero, the firms' performance will be at the level -0.8110 . It shows that the firms are not achieving any financial performance without any ownership, either managerial ownership or foreign ownership. Then, the increasing of one unit of managerial ownership, the ROA increased by 0.3092 unit, by possessing the other factors constant. Both variables are correlated to each other. Moreover, when the foreign ownership increase by one unit, the ROA will also increase by 0.2925 which means that each variable are positively correlated to each other. Next, the results of the R-squared for the model which is 0.5967 tells that $59.67 \%$ of the variation in ROA is explained by the explanatory variables. The remaining $40.33 \%$ is attributed to the factors that included in the error terms. R-squared measures the strength of the relationship between your model and the dependent variable on a convenient 0 $-100 \%$ scale.

As a conclusion from the result above, we reject the hypotheses because the value is 0.7297 which is not statistically significant as it is more than 0.01 significance level. However, they have positive relationship. This indicates that the higher the managerial ownership, the ROA also higher. Same with the last variable, the value is 0.7857 which is not statistically significant as it is more than 0.01 significance level. Therefore, the hypothesis is rejected. Be that as it may, it indicates that as the FO higher, the ROA also tend to be higher. From overall result, it can be concluded that even though the 
ROA is not significant with managerial ownership and foreign ownership, but they tend to have positive relationship. The panel regression model in this study has passed the normality test which shows that there is no autocorrelation and multicollinearity problem existed in the model. The results from the Eviews10 showed that the managerial ownership and foreign ownership have insignificant relationship between the firms in finance sector that listed in Bursa Malaysia which is positively correlated to each other. The findings in this chapter were valid and it showed inconsistencies as compared to prior studies.

\section{Conclusion}

This study was conducted with the objective to examine the correlation between ownership structure and firms' performance of finance sector listed in Bursa Malaysia. The study covers from the year 2010 to the 2014 which means the study conducted for the performance of five years. Overall, the empirical findings suggest managerial ownership and foreign ownership, both are not significant with the firms' performance. However, although the variables are not significant, the results showed positive relationship between managerial ownership and return on assets (ROA). Meanwhile, the foreign ownership has negative relationship with return on assets (ROA). Consequently, the evidence does not provide significant enough results, suggesting that the present investigation concerning foreign ownership is a sensitive piece of market share indicator to quantify for firm performance. In future research, it is recommended to explore the connection between proprietorship structure and market share. This will provide an alternate point of view from various dimensions for improvement in the results. Other different variables, for example, the institutional and family proprietorship is also suggested to quantify for firms' performance. It will be interesting to see whether firm performance differs according to market conditions. Moreover, future research ought to examine the system of the examination for over one year. In that, they should utilize time series or panel data which may get new outcomes to enhance the structure suffocate by the present investigation.

This study has some limitations but these limitations did not influence the results of the study in a significant manner. Also, chances for improving the future research was provided by such limitations as described below. First, the sample size used for this research was small. Since the focus of this study was on the finance sector in Malaysia, the sample size was limited to only 14 firms from the whole finance sector. However, it cannot be denied that larger sample size can offer more accurate results. Then, the period of study was insufficient and inadequate that only covered five years, which is from 2010 to 2014. The limitation of time range was due to some of the firms disclose only the most recent years. Next, the annual report and some of the firms do not disclose annual report before the year 2010. Also, there is data incompleteness due to the data more than this timeframe is unavailable in Faculty Economic and Business DataStream.

\section{References}

Alabdullah, T. T. (2018). The relationship between ownership structure and firm financial performance. Benchmarking: An International Journal, 25(1), 319-333. https://doi.org/10.1108/bij-04-2016-0051

Bebchuk, L. A., Cohen, A., \& Wang, C. C. (2013). Learning and the disappearing association between governance and returns. Journal of Financial Economics, 108(2), 323-348. https://doi.org/10.1016/j.jfineco.2012.10.004 
INTERNATIONAL JOURNAL OF ACADEMIC RESEARCH IN BUSINESS AND SOCIAL SCIENCES

Vol. 10, No. 7, July, 2020, E-ISSN: 2222-6990 @ 2020 HRMARS

Claessens, S., \& Yurtoglu, B. (2012). Corporate governance and development. https://doi.org/10.1596/26874.

Demsetz, H. (1983). The structure of ownership and the theory of the firm. The Journal of Law and Economics, 26(2), 375-390. https://doi.org/10.1086/467041.

Demsetz, H., \& Lehn, K. (1985). The structure of corporate ownership: Causes and consequences. Journal of Political Economy, 93(6), 1155-1177. https://doi.org/10.1086/261354.

Denis, D. K., \& McConnell, J. J. (2002). International corporate governance. SSRN Electronic Journal. https://doi.org/10.2139/ssrn.320121.

Eisenhardt, K. M. (1989). Agency theory: An assessment and review. The Academy of Management Review, 14(1), 57. https://doi.org/10.2307/258191

Epps, R. W., \& Ismail, T. H. (2009). Board of directors' governance challenges and earnings management. Journal of Accounting \& Organizational Change, 5(3), 390-416. https://doi.org/10.1108/18325910910986981

Fama, E. F., \& Jensen, M. C. (1983). Separation of ownership and control. The Journal of Law and Economics, 26(2), 301-325. https://doi.org/10.1086/467037

Gedajlovic, E., Yoshikawa, T., \& Hashimoto, M. (2005). Ownership structure, investment behaviour and firm performance in Japanese manufacturing industries. Organization Studies, 26(1), 735. https://doi.org/10.1177/0170840605046346

Goethals, J., \& Ooghe, H. (1997). The performance of foreign and national take-overs in Belgium. European Business Review, 97(1), 24-37. https://doi.org/10.1108/09555349710156037.

Gunduz, L., \& Tatoglu, E. (2003). A comparison of the financial characteristics of group affiliated and independent firms in Turkey. European Business Review, 15(1), 48-54. https://doi.org/10.1108/09555340310455191

Jensen, M. C., \& Ruback, R. S. (1983). The market for corporate control. Journal of Financial Economics, 11(1-4), 5-50. https://doi.org/10.1016/0304-405x(83)90004-1

Johnson, S., Boone, P., Breach, A., \& Friedman, E. (2000). Corporate governance in the Asian financial crisis. Journal of Financial Economics, 58(1-2), 141-186. https://doi.org/10.1016/s0304405x(00)00069-6

La Porta, R., Lopez-de-Silanes, F., Shleifer, A., \& Vishny, R. (2000). Investor protection and corporate governance. Journal of Financial Economics, 58(1-2), 3-27. https://doi.org/10.1016/s0304405x(00)00065-9.

Lemmon, M. L., \& Lins, K. V. (2003). Ownership structure, corporate governance, and firm value: Evidence from the east Asian financial crisis. The Journal of Finance, 58(4), 1445-1468. https://doi.org/10.1111/1540-6261.00573.

Li, D., Moshirian, F., Nguyen, P., \& Tan, L. (2007). Managerial ownership and firm performance: Evidence from China's privatizations. Research in International Business and Finance, 21(3), 396-413. https://doi.org/10.1016/j.ribaf.2007.02.001.

Mollah, S., Al Farooque, O., \& Karim, W. (2012). Ownership structure, corporate governance and firm performance. Studies in Economics and Finance, 29(4), 301-319. https://doi.org/10.1108/10867371211266937

Morck, R., Shleifer, A., \& Vishny, R. W. (1988). Management ownership and market valuation. Journal of Financial Economics, 20, 293-315. https://doi.org/10.1016/0304-405x(88)90048-7 
INTERNATIONAL JOURNAL OF ACADEMIC RESEARCH IN BUSINESS AND SOCIAL SCIENCES

Vol. 10, No. 7, July, 2020, E-ISSN: 2222-6990 @ 2020 HRMARS

Mudambi, R., \& Nicosia, C. (1998). Ownership structure and firm performance: Evidence from the UK financial services industry. Applied Financial Economics, 8(2), 175-180. https://doi.org/10.1080/096031098333159

Payne, P. M., Berle, A. A., \& Means, G. C. (1933). The modern Corporation and private property. Virginia Law Review, 20(1), 132. https://doi.org/10.2307/1066523

Rajagopalan, N., \& Zhang, Y. (2008). Corporate governance reforms in China and India: Challenges and opportunities. Business Horizons, 51(1), 55-64.

https://doi.org/10.1016/j.bushor.2007.09.005

Venkatraman, N., \& Ramanujam, V. (1986). Measurement of business performance in strategy research: A comparison of approaches. Academy of Management Review, 11(4), 801-814. https://doi.org/10.5465/amr.1986.4283976.

Vural-Yavas, C. (2016). Determinants of capital structure for firms that provide high quality sustainability reporting. Journal of Management and Sustainability, 6(4), 22. https://doi.org/10.5539/jms.v6n4p22. 